\title{
Influence of climatic factors on the abundance of Culex pipiens and Cx. quinquefasciatus (Diptera: Culicidae) adults in the Western Coast of Saudi Arabia
}

\author{
M.I. Hassan, ${ }^{1}$ M.A. Kenawy, ${ }^{2}$ H.A. Al Ashry, ${ }^{3}$ M. Shobrak ${ }^{4}$ \\ ${ }^{1}$ Zoology Department, Faculty of Science, Al-Azhar University, Nasr City, Cairo, Egypt; ${ }^{2}$ Department of Entomology, \\ Faculty of Science, Ain Shams University, Abbassia, Cairo, Egypt; ${ }^{3}$ TRAP Pest Control and Garden Maintenance Co. \\ Ltd., Jeddah, Saudi Arabia; ${ }^{4}$ Biology Department, Science College, Taif University, Taif, Saudi Arabia
}

\begin{abstract}
This study aims to examine the effect of weather factors, temperature $(\mathrm{T})$, relative humidity $(\mathrm{RH})$ and wind velocity $(\mathrm{WV})$ on the abundance of $C x$. (Cux.) pipiens L. and Cx. (Cux.) quinquefasciatus Say, the two common and important mosquito species in the western coast of Saudi Arabia. The two species had the same ranges of $\mathrm{T}\left(15.00-30.00^{\circ} \mathrm{C}\right)$, $\mathrm{RH}(8.00-72.00 \%)$ and $\mathrm{WV}(0.10-$ $8.06 \mathrm{Km} / \mathrm{h})$. Cx. quinquefasciatus had insignificantly $(\mathrm{P}>0.05)$ lower means of the three factors than those of $C x$. pipiens. Regression analysis indicated that abundance of $C x$. pipiens and $\mathrm{Cx}$. quinquefasciatus negatively related to $\mathrm{T}$ (regression coefficient, $\mathrm{b}=-0.06$ and -0.01 for the two species, respectively) and WV $(b=-0.40$ and -0.16 for the two species, respectively) and positive-
\end{abstract}

Correspondence: Mohamed A. Kenawy, Department of Entomology, Faculty of Science, Ain Shams University, Abbassia, Cairo 11566, Egypt.

Tel.: + 202.24821633 / 24821096 / 24821031 , Ext: 711.

Fax: +202.26839622 .

E-mail: mohamedkenawy85@yhoo.com,

mohamedkenawy330@gmail.com

Key words: Mosquitoes; Culex pipiens; Cx. quinquefasciatus; Adult abundance; Climatic factors; Western coast; Saudi Arabia.

Contributions: the authors contributed equally.

Conflict of interest: the authors declare no potential conflict of interest.

Received for publication: 5 December 2016.

Revision received: 22 March 2017.

Accepted for publication: 30 March 2017.

CCopyright M.I. Hassan et al., 2017

Licensee PAGEPress, Italy

Journal of Entomological and Acarological Research 2017; 49:6442 doi:10.4081/jear.2017.6442

This article is distributed under the terms of the Creative Commons Attribution Noncommercial License (by-nc 4.0) which permits any noncommercial use, distribution, and reproduction in any medium, provided the original author(s) and source are credited. ly related to $\mathrm{RH}(\mathrm{b}=0.05$ for both species). Such factors accounted for $81 \%$ and $76 \%$ of the variance in abundance of $C x$. pipiens and CX. quinquefasciatus, respectively while the remaining parts $(19 \%$ and $24 \%$ for the two species, respectively) may be attributed to other factors mainly rainfall.

\section{Introduction}

Thirty two mosquito species belonging to 7 genera are indigenous in the western part of the Kingdom: 14 Anopheles, 12 Culex, 2 Ochlerotatus, and 1 species each of Lutzia, Stegomyia, Culiseta and Uranotaenia (Ai-Ali et al., 2008; Al-Ghamdi et al., 2008; Alahmed et al., 2009; Kheir et al., 2010; Al Ahmad et al., 2011; Khater et al., 2013; Alikhan et al., 2014; Mahyoub et al., 2015). In a recent survey in the western coast (Hassan et al., 2016b), 19 species were identified of which Cx. pipiens (22.24\% larvae, $27.42 \%$ adults) and $C x$. quinquefasciatus (47.11\% larvae, $57.52 \%$ adults) were the common species. The two species are the chief vectors of bancroftian filariasis, Wuchereria bancrofti in many parts of the world including the Middle East and Eastern Mediterranean countries (Ai-Ali et al., 2008; Samy et al., 2016). Omar (1996) reported that Cx. pipiens may act as a potential vector of introduced bancroftian filariasis to Saudi Arabia. In addition, $C x$. pipiens and $C x$. quinquefasciatus act as vectors of West Nile Virus (Al-Ali et al., 2008; Samy et al., 2016).

To control mosquitoes, a good knowledge and understanding of the relevant biology and ecology of the target species is of paramount importance (Seghal \& Pillai, 1970; Gimnig et al., 2001). Understanding climatic factors (temperature, relative humidity and rainfall) influencing adults and larvae is the first step to control over mosquito vector survival, production, development, abundance and distribution (Jemal \& Al-Thukair, 2016). Temperature and rainfall were found to be closely associated with mosquito density (Tian et al., 2015). The temperature affects the abundance and activity of mosquitoes; for example high temperature accelerates mosquito development from egg to adult and increases their abundance (Tun-Lin et al., 2000; Hopp \& Foley, 2001; Bayoh \& Lindsay, 2003; Alahmed, 2012; Alshehri, 2013). However, it was reported that temperature greater than $30^{\circ} \mathrm{C}$ decreases mosquito survivorship and abundance (Westbrook et al., 2010; Christiansen-Jucht et al., 2014). The relative humidity is often increased by rainfall, particularly following drought and 
strongly affects the number of females laying eggs, the number of eggs laid, feeding frequency, survival, flight and subsequent host seeking behavior of mosquitoes (Day \& Curtis, 1989; Reiter, 2001; Ceccato et al., 2005). Different studies have indicated that high RH increases mosquito lifespan, hatching, density, survival and abundance (Hopp \& Foley, 2001; Reiter, 2001; Murty et al., 2010; Alahmed, 2012; Alshehri, 2013; Tian et al., 2015). Moreover, rainfall and $\mathrm{RH}$ were the most significant variables influencing anopheline density but the effects of temperature were not found as a significant variable on the abundance of anopheline mosquitoes in Bangladesh (Bashar \& Tuno, 2014).

Very few studies were carried out in Saudi Arabia to examine the effect of climatic factors (temperature, relative humidity and rainfall) on mosquito abundance; these studies considered the dengue vector Stegomyia aegypti (Al-Ghamdi et al., 2009; Alshehri, 2013) above all. Jemal \& Al-Thukair (2016) examined the effect of these factors on mosquito abundance of three genera (Culex, Aedes and Anopheles) in the Eastern Province. However, no studies were carried out on $C x$. pipiens and $C x$. quinquefasciatus adults, this study was planned and aimed at examining the effect of the climatic factors (temperature, relative humidity and wind velocity) on abundance of these two common and important mosquito species in the western coast.

\section{Materials and Methods}

\section{The study area}

The Western part of the Kingdom of Saudi Arabia $\left(16^{\circ}\right.$ and $33^{\circ}$ $\mathrm{N}, 34^{\circ}$ and $56^{\circ} \mathrm{E}$ ) includes the west coast north of Asir. It contains a mountain chain (with peaks rising to 3000 meters) and the coastal plain bordering the Red Sea. It also includes the most cosmopolitan city of Jeddah which is the main port for thousands of pilgrims on their trip to Holy Cities of Mecca (to the east) and Al Madinah (to the north). In the mountains above Mecca and Jeddah is the town of Taif. Its elevation gives it a climate far cooler than either Jeddah or Mecca and without the uncomfortable humidity of these two cities. The coastal area of the Western part (1090 km long) is notorious for its humidity, with summer temperatures rising to above $40^{\circ} \mathrm{C}$. Three regions representing this part: Mecca " $21^{\circ} 252$ $\mathrm{N} 39^{\circ} 49^{\prime} \mathrm{E}$ ”, Al Madinah “ $25^{\circ} 0^{\prime} \mathrm{N} 39^{\circ} 30^{\prime} 30^{\prime \prime} \mathrm{E}$ and Tabouk “ $28^{\circ} 0$ 'N $37^{\circ} 0^{\prime} \mathrm{E} "$.

The study was carried out in four sea ports (Jeddah: $21^{\circ} 32^{\prime} 36^{\prime \prime} \mathrm{N} 39^{\circ} 10^{\prime} 22^{\prime \prime} \mathrm{E}$, Yanbu: $24^{\circ} 05^{\prime} \mathrm{N} 38^{\circ} 00^{\prime} \mathrm{E}$, Duba: $27^{\circ} 20^{\prime} 57.3^{\prime \prime} \mathrm{N} 35^{\circ} 41^{\prime} 46.2^{\prime \prime} \mathrm{E}$ and Haql: $\left.29^{\circ} 17^{\prime} \mathrm{N} 34^{\circ} 56^{\prime} \mathrm{E}\right)$ and two cities (Taif: $21^{\circ} 26^{\prime} \mathrm{N} 40^{\circ} 21^{\prime} \mathrm{E}$ and Mecca: $21^{\circ} 30^{\prime} \mathrm{N} 41^{\circ} 0^{\prime} \mathrm{E}$ ) representing the three regions (Figure 1). In each locality, certain sites were selected and biweekly surveyed for mosquitoes during the period from January 2013 to December 2014.

\section{Mosquito sampling}

Adults were collected using three different types of traps: i) the CDC (Center for Disease Control) miniature light traps (Model 512, John W. Hock Co., Gainesville, FL, USA), ii) V-Mart Super photo-catalyst Black Hole (BH) traps (Venus Technology Co., Ltd. Wangthonglang, Bangkok, Thailand) and iii) UV traps (John W. Hock Company, Gainesville, FL, USA). The traps were set before sunset and collected after sunrise next morning. The collected mosquitoes were aspirated, placed in labeled paper cups that kept in a picnic ice box while being transported to the laboratory. In the laboratory, mosquitoes were preserved in $70 \%$ alcohol till identification to the species level according to keys of Mattingly \& Knight (1956) and Harbach (1985; 1988).
The weather temperature and Relative Humidity $(\mathrm{RH})$ were measured using 2-in-1 LCD Digital Thermometer Hygrometers Model: TA328 and wind velocity $(\mathrm{Km} / \mathrm{h})$ was measured using Digital Anemometer Model: AM-4203 (Lutrun Electronic Inc., Coopersburg, PA, USA).

\section{Data analysis}

The data collected during 2013 and 2014 from all localities were compiled and considered for data analysis. Means \pm SD were calculated for T, RH and WV of the two mosquito species and tested for significance by the one-way ANOVA. Multiple Regression analysis was used to examine the relation of adult abundance (No collected/trap of all types) with T, RH and WV. The regression equations were in the form of:

$$
\text { adult abundance }=\mathrm{a}+\mathrm{b}_{1} \mathrm{~T}+\mathrm{b}_{2} \mathrm{RH}+\mathrm{b}_{3} \mathrm{WV} \text {, }
$$

where $a=$ constant (intercept), $b_{1}-b_{3}$ are the slopes (regression coefficients). The slopes were tested for deviation from 0 by t-test. The PAST (Paleontological Statistics Version 2.08; Hammer et al., 2001) computerized software was used for statistical analysis.

\section{Results}

\section{Ranges of the weather temperature, relative humidity and wind velocity}

The ranges of the weather T, RH and WV were determined for $C x$. pipiens and Cx. quinquefasciatus and results (Table 1) revealed that the two species had the same ranges of $\mathrm{T}\left(15.00-30.00^{\circ} \mathrm{C}\right), \mathrm{RH}$ $(8.00-72.00 \%)$ and $\mathrm{WV}(0.10-8.06 \mathrm{Km} / \mathrm{h}) . C x$. quinquefasciatus had insignificantly $(\mathrm{P}>0.05)$ lower means of $\mathrm{T}\left(25.20^{\circ} \mathrm{C}\right), \mathrm{RH}$ $(36.63 \%)$ and $\mathrm{WV}(2.24 \mathrm{Km} / \mathrm{h})$ than those of $C x$.pipiens $\left(25.53^{\circ} \mathrm{C}\right.$, $38.36 \%$ and $2.33 \mathrm{Km} / \mathrm{h}$ for the 3 factors, respectively)

\section{Relation of mosquito abundance with the temperature, relative humidity and wind velocity}

The results of multiple regression analysis (Table 2) indicate that: i) abundance of $C x$. pipiens $(\mathrm{b}=-0.06, \mathrm{t}=1.09, \mathrm{P}>0.05)$ and $C x$. quinquefasciatus $(\mathrm{b}=-0.01, \mathrm{t}=0.13, \mathrm{P}>0.05)$ is inversely related to

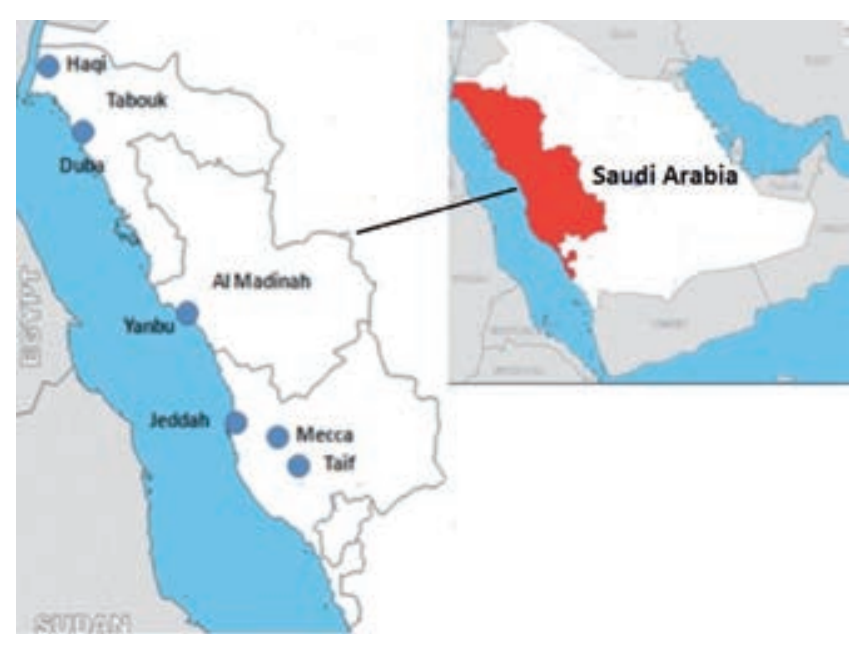

Figure 1. Surveyed localities in the western part of Saudi Arabia. 
$\mathrm{T}$, i.e. decreases as $\mathrm{T}$ increases, ii) abundance of $C x$. pipiens $(\mathrm{b}=0.05, \mathrm{t}=1.92, \mathrm{P}>0.05)$ and $C x$. quinquefasciatus $(\mathrm{b}=0.05$, $\mathrm{t}=1.12, \mathrm{P}>0.05)$ is directly related to $\mathrm{RH}$, i.e. increases as $\mathrm{RH}$ increases, iii) abundance of $C x$. pipiens $(\mathrm{b}=-0.40, \mathrm{t}=1.54, \mathrm{P}>0.05)$ and $C x$. quinquefasciatus $(\mathrm{b}=-0.16, \mathrm{t}=0.32, \mathrm{P}>0.05)$ is inversely related to $\mathrm{WV}$, i.e. decreases as $\mathrm{WV}$ increases.

\section{Discussion and Conclusions}

In the present study, $C x$. pipiens and $C x$. quinquefasciatus had the same ranges of $\mathrm{T}\left(15.00-30.00^{\circ} \mathrm{C}\right), \mathrm{RH}(8.00-72.00 \%)$ and $\mathrm{WV}$ $(0.10-8.06 \mathrm{Km} / \mathrm{h})$. No comparable results for these two mosquito species in the study area or in any other area of the Kingdom were available. In the Eastern Province, Jemal \& Al-Thukair (2016) determined the effect of T, RH and rainfall on mosquito abundance of 3 genera (Culex, Aedes and Anopheles) and showed that T of 15$27^{\circ} \mathrm{C}$ and $\mathrm{RH}$ between $4 \%$ and $69 \%$ favors the high abundance and spread of the adult mosquitoes and that $\mathrm{T}$ greater than $35^{\circ} \mathrm{C}$ in summer season is unsuitable for adult mosquito growth. Similarly, in Jeddah city, $\mathrm{T}$ range from $20^{\circ} \mathrm{C}$ to $29^{\circ} \mathrm{C}$ favors the increase in Aedes aegypti density and during summer months the average $\mathrm{T}$ is more than $40^{\circ} \mathrm{C}$ which is not suitable for rapid mosquito growth (Alshehri, 2013). Christiansen-Jucht et al. (2014) indicated that higher environmental temperatures ( $\operatorname{than} 30^{\circ} \mathrm{C}$ ) significantly lower adult survival and increase adult mortality $(\mathrm{P}<0.001)$, however it was reported that high $\mathrm{T}$ speeds up mosquito growth and increases mosquito abundance (Tun-Line et al., 2000; Hopp \& Foley, 2001; Alahmed, 2012). Other authors (Bayoh \& Lindsay, 2003; Tan et al., 2015) indicated that temperatures of $20-29^{\circ} \mathrm{C}$ are favorable for mosquito growth and development. Abdel-Hamid et al. (2011b) in El Ismailia Governorate, Egypt, found that both $C x$. pipiens and $C x$ antennatus had $\mathrm{T}$ range of $16-22.7^{\circ} \mathrm{C}$ and $\mathrm{RH}$ range of $43.8-73.9 \%$.

Regression analysis indicated that abundance of the two species insignificantly $(\mathrm{P}>0.05)$ decreases as both $\mathrm{T}$ and $\mathrm{WV}$ increase and abundance increases as RH increases. Such result reflects the seasonality trends of these two species. In a concurrent study (Hassan et al., 2016a), adults of the two species were active all year round with peaks of abundance during spring, i.e. during the mild temperature $\left(\right.$ mean $\approx 26^{\circ} \mathrm{C}$ ) and $\mathrm{RH}($ mean $=48 \%$ ). High activity was also observed during autumn $\left(\approx 28^{\circ} \mathrm{C}, 50 \% \mathrm{RH}\right)$ for
Cx. pipiens and during winter $\left(\approx 21^{\circ} \mathrm{C}, 58 \% \mathrm{RH}\right)$ for the two species, while lower activity was observed during summer with high mean temperature $\left(\approx 33^{\circ} \mathrm{C}\right)$ and lower $\mathrm{RH}(42 \%)$.

There was no study examining the effect of weather factors $(\mathrm{T}$, $\mathrm{RH}$ and $\mathrm{WN}$ ) on abundance of these two species in the western part of Saudi Arabia. However, similar findings were reported by Jemal \& Al-Thukair (2016) in the Eastern Province (6 studied localities) who found i) strong negative correlation between mosquito abundance and $\mathrm{T}(\mathrm{R}=-0.867)$, ii) a strong positive correlation with $\mathrm{RH}(\mathrm{R}=0.654)$. Other available studies in Saudi Arabia are dealing with the dengue vector, St. aegypti. Al-Ghamdi et al. (2009) found that the role of RH on the seasonal abundance of Aedes mosquitoes in Jeddah is well established compared to other climatic variables. Alshehri (2013) in Jeddah city, showed a strong correlation between Aedes aegypti density and climatic factors ( $\mathrm{T}$ and $\mathrm{RH}$ ), but no significant influence of rainfall was visible on mosquito density. Several studies were carried out on Egyptian $C x$ pipiens, $C x$. antennatus and $C x$. perexiguus mosquitoes and indicated that abundance: i) increases as $\mathrm{T}$ and $\mathrm{RH}$ increase in $\mathrm{El}$ Sharqiya Governorate (Abdel-Hamid et al., 2009), ii) insignificantly $(\mathrm{P}>0.05)$ decreases as $\mathrm{T}$ and $\mathrm{RH}$ increase in El Menoufia Governorate (Abdel-Hamid et al., 2011a) and iii) insignificantly $(\mathrm{P}>0.05)$ increases as $\mathrm{T}$ increases, while decreases as RH increases in El Ismailia and El Dakahlia Governorates (Abdel-Hamid et al., 2011b; 2013).

The regression model with abundance as criterion variable and the three weather factors (T, RH and WV) as predictor variables showed that $81 \%(\mathrm{R}=0.81)$ for $C x$. pipiens and $76 \%(\mathrm{R}=0.76)$ for $C x$. quinquefasciatus of the total variance were accounted, in agreement with observation of Jemal \& Al-Thukair (2016) for T, $\mathrm{RH}$ and rainfall $(84.5 \%, \mathrm{R}=0.845)$, while Alshehri (2013) showed that the three climatic parameters ( $\mathrm{T}, \mathrm{RH}$ and rainfall) accounted for $24 \%$ of variance in density of Aedes aegypti mosquito. The remaining 19\% (Cx. pipiens) and 24\% (Cx. quinquefasciatus) of the variance may be attributed to other factors mainly rainfall that have moderate positive correlation with mosquito abundance $(\mathrm{R}=0.147)$ (Jemal \& Al-Thukair, 2016) and is considered the most significant variable influencing anopheline density (Bashar \& Tuno, 2014).

In conclusion, the results of this study demonstrate that the two mosquito species respond to similar weather conditions and that their abundance had an indirect relation with weather $\mathrm{T}$ and $\mathrm{WV}$

Table 1. Ranges and means of the weather temperature (T), relative humidity (RH) and wind velocity (WV) for the two common mosquito species.

\begin{tabular}{|c|c|c|c|c|c|}
\hline \multirow{2}{*}{ Attribute } & \multicolumn{2}{|c|}{ Cx. pipiens } & \multicolumn{2}{|c|}{ Cx. quinquefasciatus } & \multirow[t]{2}{*}{$\mathbf{F}_{(1,18)}$} \\
\hline & Range & Mean \pm SD & Range & Mean \pm SD & \\
\hline $\mathrm{T}\left({ }^{\circ} \mathrm{C}\right)$ & $15.00-30.00$ & $25.53 \pm 4.16$ & $15.00-30.00$ & $25.20 \pm 4.40$ & 0.03 \\
\hline RH (\%) & $8.00-72.00$ & $38.36 \pm 7.11$ & $8.00-72.00$ & $36.63 \pm 6.92$ & 0.29 \\
\hline $\mathrm{WV}(\mathrm{Km} / \mathrm{h})$ & $0.10-8.06$ & $2.33 \pm 0.71$ & $0.10-8.06$ & $2.24 \pm 0.55$ & 0.01 \\
\hline
\end{tabular}

Table 2. Multiple regression analysis for the effect of temperature (T), relative humidity $(\mathrm{RH})$ and wind velocity (WV) on the abundance of the two common mosquito adults.

\begin{tabular}{lcccc} 
Species & \multicolumn{3}{c}{ b (regression coefficient) } & R (correlation coefficient) \\
CX. pipiens & RH & 0.05 & -0.40 & 0.81 \\
Cx. quinquefasciatus & -0.06 & 0.05 & -0.16 & 0.76 \\
\hline
\end{tabular}


and a direct relation with $\mathrm{RH}$. Such factors accounted for $81 \%$ and $76 \%$ of the variance in abundance of $C x$. pipiens and $C x$. quinquefasciatus, respectively, while the residual variance may be attributed to other factors mainly rainfall.

\section{References}

ABDEL-HAMID Y.M., SOLIMAN M.I., ALLAM K.M., 2009 Spatial distribution and abundance of culicine mosquitoes in relation to the risk of filariasis transmission in El Sharqiya Governorate, Egypt. - Egypt. Acad. J. Biolog. Sci. 1: 39-48.

ABDEL-HAMID Y.M., SOLIMAN M.I., KENAWY M.A., 2011a - Geographical distribution and relative abundance of culicine mosquitoes in relation to transmission of lymphatic filariasis in El Menoufia Governorate, Egypt. - J. Egypt. Soc. Parasitol. 41: 109-118.

ABDEL-HAMID Y.M., SOLIMAN M.I., KENAWY M.A., 2011b - Mosquitoes (Diptera: Culicidae) in relation to the risk of disease transmission in El Ismailia Governorate, Egypt. - J. Egypt. Soc. Parasitol. 41: 347-356

ABDEL-HAMID Y.M., SOLIMAN M.I., KENAWY M.A., 2013 Population ecology of mosquitoes and the status of bancroftian filariasis in El Dakahlia Governorate, the Nile Delta, Egypt. J. Egypt. Soc. Parasitol. 43: 103-113.

AL-AHMAD A.M., SALLAM M.F., KHURIJI M.A., KHEIR S.M., AZARI-HAMIDIAN S., 2011- Checklist and pictorial key to fourth-instar larvae of mosquitoes (Diptera: Culicidae) of Saudi Arabia. - J. Med. Entomol. 48: 717-737.

ALAHMED A.M., 2012 - Mosquito fauna (Diptera: Culicidae) of the Eastern Region of Saudi Arabia and their seasonal abundance. - King Saud Univ. Sci. 24: 55-62.

ALAHMED A.M., AL KURIJI M.A., KHEIR S.M., AL AHMEDI S.A., AL HATABBI M.J., Al GASHMARI M.A.M., 2009 Mosquito fauna (Diptera: Culicidae) and seasonal activity in Makkah Al Mukarramah Region, Saudi Arabia. - J. Egypt. Soc. Parasitol. 39: 991-1013.

AI-ALI K.H., EI-BADRY A.A., EASSA A.H.A., ALJUHANI A.M., AL-ZUBIANY S.F., IBRAHIM E.D., 2008 - A study on Culex species and Culex transmitted diseases in AI-Madinah AI-Munawarah, Saudi Arabia. - Parasitol. Unit. J. 1: 101-108.

AL-GHAMDI K., ALIKHAN M., MAHAYOUB J., 2009 - Role of climatic factors in the seasonal abundance of Aedes aegypti $\mathrm{L}$. and dengue fever cases in Jeddah province of Saudi Arabia. Curr. World Environ. 4: 307-312.

AL-GHAMDI K., ALIKHAN M., MAHAYOUB J., AFIFI Z.I., 2008 - Studies on identification and population dynamics of Anopheline mosquitoes from Jeddah, Saudi Arabia. - Biosci. Biotech. Res. Commun. 1: 19-24.

ALIKHAN M., GHAMDI K.A., MAHYOUB J.A., 2014 - Aedes mosquito species in western Saudi Arabia. - J. Insect Sci. 14: 69.

ALSHEHRI M.S.A., 2013 - Dengue fever outburst and its relationship with climatic factors. - World Appl. Sci. J. 22: 506-515.

BASHAR K., TUNO N., 2014 - Seasonal abundance of Anopheles mosquitoes and their association with meteorological factors and malaria incidence in Bangladesh.- Parasit. Vectors 7: 442.

BAYOH M.N., LINDSAY S.W., 2003 - Effect of temperature on the development of the aquatic stages of Anopheles gambiae sensu strict (Diptera: Culicidae). - Bull. Entomol. Res. 93: 375-381.

CECCATO P., CONNOR S.J., JEANNE I., THOMSON M.C., 2005 - Application of geographical information systems and remote sensing technologies for assessing and monitoring malaria risk.- Parassitologia 47: 81-96.
CHRISTIANSEN-JUCHT C., PARHAM P.E., SADDLER A., KOELLA J.C., BASÁÑEZ M.G., 2014 - Temperature during larval development and adult maintenance influences the survival of Anopheles gambiae s.s. - Parasit. Vectors 7: 489.

DAY J.F., CURTIS G.A., 1989 - Influence of rainfall on Culex nigripalpus (Diptera: Culicidae) blood-feeding behavior in Indian River County, Florida. - Ann. Entomol. Soc. Am. 82: 32-37.

GIMNIG J.E., OMBOK M., KAMAU L., HAWLEY W.A., 2001Characteristics of larval anophelinae (Diptera: Culicidae) habitats in western Kenya. - J. Med. Entomol. 38: 282-288.

HAMMER Ø., HARPER D.A.T., RYAN P.D., 2001 - Past: Paleontological statistics software package for education and data analysis. Available from: http://www.nhm.uio.no/norlex/ past/download.html

HARBACH R.E., 1985 - Pictorial keys to the genera of mosquitoes, subgenera of Culex and the species of Culex (Culex) occurring in southwestern Asia and Egypt, with a note on the subgeneric placement of Culex deserticola (Diptera: Culicidae). - J. Mosq. Syst. 17: 83-107.

HARBACH R.E., 1988 - The mosquitoes of the subgenus Culex in southwestern Asia and Egypt (Diptera: Culicidae). Contrib. Amer. Ent. Inst. 24: 1-240.

HASSAN M.I., AL ASHRY H.A., SHOBRAK M., KENAWY M.A., 2016a - Seasonal Abundance of the Common Mosquitoes: Culex pipiens, $C x$. quinquefasciatus and $C x$. sitiens (Diptera: Culicidae) in the western coast of Saudi Arabia. - Egypt. Acad. J. Biolog. Sci. (E-Medical Entom. \& Parasitology) 8: 13-22.

HASSAN M.I., KENAWY M.A., AL ASHRY H.A., SHOBRAK M., 2016b - Mosquitoes (Diptera: Culicidae) of the western coastal area, Kingdom of Saudi Arabia: Species composition, abundance, diversity and medical importance. - J. Egypt. Soc. Parasitol. 47: 166-175.

HOPP M.J., FOLEY J.A., 2001 - Global-scale relationships between climate and the dengue fever vector, Aedes aegypti. Clim. Change 48: 441-463.

JEMAL Y., AL-THUKAIR A.A., 2016 - Combining GIS application and climatic factors for mosquito control in Eastern Province, Saudi Arabia. - Saudi J. Biol. Sci. [in Press].

KHATER E.I., SOWILEM M.M., SALLAM M.F., ALAHMED A.M., 2013 - Ecology and habitat characterization of mosquitoes in Saudi Arabia. - Trop. Biomed. 30: 409-427.

KHEIR S.M., AL AHMED A.M., AL KURIJI M.A., AL ZUBYANI S.F., 2010 - Distribution and seasonal activity of mosquitoes (Diptera: Culicidae) in Al Madinah Al Munwwarah Region, Saudi Arabia. - J. Egypt. Soc. Parasitol. 40: $215-227$.

MAHYOUB J.A., AL-HARBI O.S., AL-GHAMDI K.M., MANGOUD A.A.H., AL-SOLAMI H.M., 2015 - Population dynamics of different mosquito genera and species in Makkah city, Saudi Arabia. - Biosci. Biotech. Res. Comm. 8: 116-125.

MATTINGLY P.F., KNIGHT K.L., 1956 - The mosquitoes of Arabia. - Bull. Brit. Mus. (Nat. Hist.) Entomol. 4: 89-141.

MURTY U.S., RAO M.S., ARUNACHALAM N., 2010 - The effects of climatic factors on the distribution and abundance of Japanese encephalitis vectors in Kurnool district of Andhra Pradesh, India.- J. Vector Borne Dis. 47: 26-32.

OMAR M.S., 1996 - A survey of bancroftian filariasis among South-East Asian expatriate workers in Saudi Arabia. - Trop. Med. Int. Hlth. 1: 155-160.

REITER P., 2001 - Climatic change and mosquito-borne disease. Environ. Health Perspect. 109: 141-161.

SAMY A.M., ELAAGIP A.H., KENAWY M.A., AYRES C.F.J., 
PETERSON A.T., SOLIMAN D.E., 2016 - Climate Change Influences on the global potential distribution of the mosquito Culex quinquefasciatus, vector of West Nile virus and lymphatic filariasis. - PLoS One 11: e0163863.

SEGHAL S., PILLAI M.K., 1970 - Preliminary studies on the chemical nature of mosquito breeding waters in Delhi. - Bull. WHO 42: 647-650.

TIAN H.Y., BI P., CAZELLES B., ZHOU S., HUANG S.Q., YANG J., PEI Y., WU X.X., FU SH., TONG S.L., WANG H. Y., XU B., 2015 - How environmental conditions impact mos- quito ecology and Japanese encephalitis: an eco-epidemiological approach. - Environ. Int. 79:17-24.

TUN-LIN W., BURKOT T.R., KAY B.H., 2000 - Effects of temperature and larval diet on development rates and survival of the dengue vector Aedes aegypti in north Queensland, Australia. - Med. Vet. Entomol. 14: 31-37.

WESTBROOK C.J., REISKIND M.H., PESKO K.N., GREENE K.E., LOUNIBOS L.P., 2010 - Larval environmental temperature and the susceptibility of Aedes albopictus Skuse (Diptera: Culicidae) to Chikungunya virus. - Vector-Borne Zoon. Dis. 10: 241-247. 